\title{
BI systems implementation for supply chain sector in retail companies
}

\author{
Oksana Iliashenko \\ Graduate School of Business and \\ Mqnagement \\ Institute of Industrial Management, \\ Economics and Trade \\ Peter the great St. Petersburg \\ polytechnic university \\ Saint-Petersburg, Russia \\ ioy12@yandex.ru
}

\author{
Victoria Iliashenko \\ Graduate School of Business and \\ Mqnagement \\ Institute of Industrial Management, \\ Economics and Trade \\ Peter the great St. Petersburg \\ polytechnic university \\ Saint-Petersburg, Country \\ vmi1206@yandex.ru
}

\author{
Manfred Esser \\ Get IT \\ Saint-Petersburg, Russia \\ messer@myget-it.com
}

\begin{abstract}
The article describes the existing BI systems, allowing to solve data analytics issues, make forecasts, support the development of business process systems, model business situations in a single information environment. The article offers the best practice analysis of the three leading BI platforms. Based on the advantages and disadvantages, the system is selected for further use as an automated reporting system for the supply chain sector for Retail companies.
\end{abstract}

Keywords-Business Intelligence, Supply chain, retail, KPIs.

\section{INTRODUCTION}

Today, there is a growing need for real-time analytics, especially from retailers, the banking sector, and Internet companies. Analyzing data in real time increases the value of the information obtained, since it can be used to make timely managerial, operational and strategic decisions [1]. At the present stage of development of retail companies, the supply chain department plays one of the main roles in creating the efficiency of the company. The key benefits of implementing a BI system at the moment are increasing the speed and accuracy of reporting, analytics and planning, improving the efficiency of decision-making processes, increasing customer satisfaction. Systems for business analysis solve a very wide range of tasks. Thus, the "near horizon" is the monitoring, analysis and adjustment of operational objectives $[2,3,4,5]$ :

- support the development of business processes and structural changes of the enterprise;

- the ability to model various business situations in a single information environment;

- conducting operational analysis on non-standard requests;

- reduction of the routine load on the staff and the release of time for deeper analytical work;

- stable operation with an increase in the amount of information processed, the ability to scale [6].

\section{RESEARCH METHODS}

The main research methods in this article are:

- analysis of existing solutions using BI platforms in the retail sector;
- creating a data model and developing dashboards based on the chosen BI platform.

\section{LITERATURE REVIEW}

Consider the possibilities and examples of using leading BI systems: Tableau, Power BI, QlikView.

\section{A. Tableau BI system}

Tableau solutions are designed to analyze data and identify information that is valuable for business with minimal costs for system implementation, employee training and maintenance in the future. The Tableau platform is based on two innovative technologies: VizQL, through which you can create complex visualizations with a mouse click, and the Data Engine, which provides analysis of millions of rows per second [7].

Tableau today is used by tens of thousands of users in 100 countries, including Amazon, BP, Apple, Walmart, Heineken, Starbucks, Pfizer, Coca-Cola, Bank of America and Barclays, Institute for the Study of Violent Groups (ISVG) , Mazda, Knaufinsulation. A number of Russian companies also use Tableau: Avito, Lamoda, Wildberries, Megafon LLC, Credit Bank of Moscow, Russian Pharmaceutical Company Materia Medica, Russia's largest provider of digital services and solutions, PJSC Rostelecom ", Tinkoff Bank, Svyaznoy Logistics company, Project 111 company and etc [8].

The use of Tableau gives companies a number of advantages.

For example, INRIX, a leading global provider of information on traffic and driving services, has about 50 petabytes of data from all over the world. Using Tableau, the company quickly analyzes data from more than 1 million roads in North America and more than 1.5 million in Europe, building various graphs and charts, on the basis of which reports such as the INRIX Gridlock Index (IGI) and National Traffic Scorecard report are then created [9]. The company will use Tableau's capabilities to determine where to build a new road, or to evaluate the profitability of an existing road, or how best to get from point $\mathrm{A}$ to point $\mathrm{B}$, taking into account traffic.

DataSift is a leading social data platform that provides access to open data from various social networks (Facebook, 
Twitter, Instagram, etc.). Obviously, today social networks are an extremely important source of information that companies need to use. The partnership between Tableau Software and DataSift allowed us to solve the problem of in-depth consumer analysis, which will provide answers to such questions as: Who are our customers? What exactly are they interested in? How to attract new?

Institute for the Study of Violent Groups (ISVG) is a research center at the University of New Haven. This center collects data on extremism, terrorism and all sorts of crimes. After studying this data, the results are provided to various government organizations.

Recently, ISVG began to use Tableau Software for analyzing reports and data. If earlier the institute issued several reports a year, now they build a lot of reports in just one week. At the same time, students of the institute find more and more interesting facts, for example, in which areas crimes are committed more often than in others, which terrorist groups are more active and much more.

\section{B. Qlik BI system}

Solutions on the Qlik platform are the most popular in Russia in various areas - financial, industrial, oil and gas sector. The retail industry is no exception. Large supermarket chains use Qlik solutions to monitor sales volumes, analyze customer behavior, etc $[10,11]$.

Consider an example of implementing solutions on the Qlik platform in a retail enterprise. The Russian retail network Lenta has implemented an analytical solution that allows it to work quickly with a huge amount of retailer data at a qualitatively new level. The system, created on the QlikView platform, deeply and accurately analyzes the complete outline of information on Lenta's activities: from the network's business results and store inventories to personnel performance indicators. The BI solution allows to analyze the factors affecting sales (number of buyers, margin, availability of goods in the store, lost sales, etc.) and the results of promotions.

In addition, the new tool is designed to analyze data on the level of execution of orders by suppliers and distribution centers, the level of availability of goods and lost sales, the stock of goods for sale. He is also able to give a qualitative assessment of the product in terms of insufficiency / redundancy and liquidity [12].

\section{Power BI system}

Power BI is one of the world leaders in the field of BI systems. Many large business players use Power BI solutions to solve all kinds of analytical tasks in order to make strategic business development decisions. Heathrow, Hewlet Packard, Meijer, Aston Martin, Rolls-Royce, Associated Press, Henkel, Devon, Kennametal Stellite, Seahawks, Edsby, etc.

Consider one of the examples of Power BI implementation in retail sector. The Meijer supermarket chain, one of the largest US private companies, has become dependent on its IT organization for information from its data. To achieve flexibility, the company decided to use a flexible BI environment.

The company successfully implemented a project in which the Power BI platform was connected to the local OLAP cube of SQL Server Analytics Services. As a result, 20 billion data lines were updated almost in real time. Using Power BI and SQL Server Analysis Services, teams can extract the necessary data and ask their own questions instead of creating a solution that answers each question [13]

The analysis of the use of the three largest business analysis systems - Tableau, Qlik, Power BI - allows us to conclude about the large-scale use of BI systems in various sectors of the economy: financial, energy, retail, manufacturing, medical, etc. The reviewed business analysis systems offer both industry-specific and functional solutions: finance, sales, warehouse, HR, marketing, demand forecast based on secondary sales data, etc. The main business results of implementing BI solutions are [14]:

- the ability to access complete and detailed information about the business;

- the possibility of operational and strategic analysis, which contributes to improved management efficiency.

Based on the main advantages of each BI platform, a QlikView system was chosen to implement the creation of reports in connection due to [15]:

- a wide range of functions that help create advanced dashboards based on data from a variety of sources;

- the tool ability to automatically recognize the relationships between the data without any preliminary configuration from the user, which speeds up the process of creating reports and dashboards

- storing data in the server's RAM, which significantly speeds up the execution of requests, and hence the analysis of data.

\section{RESULTS}

During the research, the main BI systems focused on the application of an automated reporting and analysis system on the QlikView platform to create dashboards that allow evaluating the work of the retail supply chain management service. The main goals of the created report are [16]:

- the provision of up-to-date information on the financial performance of the supply chain management service to manage the company and improve the efficiency of business processes;

- improved user friendliness and indicator integrity;

- reducing of report time creating;

- the ability for the user to obtain the necessary data in the section of interest quickly without additional requests to other services.

\section{A. Data sources}

At this architecture level, the data source for the analysis coming into the system are reflected. The system implements integration functions with external sources - forms implemented in MS Excel format and customer's accounting / analytical systems on the SAP platform. The first category of sources is MS Excel files sources. The second category of sources is system sources. The system source for the 
information analytical system will be the SAP BW system. For all data loaders from system sources, use an external connection string. The connection string must be saved to a separate QlikView script file and connected to all loaders via the Must_Include variable. To download the data, the specialized software "Qlik Connector powered by SAP NetWeaver" will be used.

\section{B. Report tabs}

Report tabs include Dashboard and OpenSearch. Dashboard contains data on the key financial indicators of the company and the supply chain management unit in particular, as well as the display of key indicators reflecting the efficiency of the supply chain management service processes. OpenSearch is considered as a tool for self-creation of tables based on the parameters selected by the user.

Table 1 presents the main composition of the characteristics used in the report:

TABLE I.

\begin{tabular}{|c|c|c|}
\hline $\begin{array}{c}\text { Attribute } \\
\text { composition }\end{array}$ & Measurement & Comment \\
\hline Period & Month & Selected month \\
\cline { 2 - 3 } & Quarter & $\begin{array}{c}\text { Cumulatively from the beginning } \\
\text { of the selected quarter to the } \\
\text { month }\end{array}$ \\
\cline { 2 - 3 } & Year & $\begin{array}{c}\text { Cumulatively from the beginning } \\
\text { of the selected year to the month }\end{array}$ \\
\hline $\begin{array}{c}\text { Hierarchy of } \\
\text { supply chain } \\
\text { management } \\
\text { service }\end{array}$ & $\begin{array}{c}\text { Store service } \\
\text { format } \\
\text { (Total/HM/SM) }\end{array}$ & $\begin{array}{c}\text { All Store / Hypermarkets / } \\
\text { Supermarkets }\end{array}$ \\
\cline { 2 - 3 } & Store status & $\begin{array}{c}\text { Total/ (A/R LFL/NSO PY/NSO } \\
\text { CY) }\end{array}$ \\
\cline { 2 - 3 } & Cost Center & SC Total/SCM/Transport/DC \\
\cline { 2 - 3 } & SCM & 5+ elements (office departments) \\
\cline { 2 - 3 } & $\begin{array}{c}\text { Type of store } \\
\text { ownership }\end{array}$ & Owned/rented (2 elements) \\
\hline
\end{tabular}

The table below presents the main indicators (baseline and calculated) used in the reports:

TABLE II.

\begin{tabular}{|c|c|c|}
\hline $\begin{array}{l}\text { Main } \\
\text { indicators }\end{array}$ & Indicator & Description \\
\hline 1 & Sales & $\begin{array}{c}\text { The company's sales in } \\
\text { sales prices }\end{array}$ \\
\hline 2 & Total income & Total income \\
\hline 3 & Total operational costs & Total operational costs \\
\hline 4 & OEBITDA* & $\begin{array}{l}\text { Profit before tax, interest } \\
\text { on loans and depreciation }\end{array}$ \\
\hline 5 & OEBIT* & $\begin{array}{c}\text { Profit before tax, interest } \\
\text { on loans (excluding } \\
\text { depreciation) }\end{array}$ \\
\hline 6 & $\begin{array}{l}\text { Inbound to store from DC } \\
\text { (Centralized turnover) }\end{array}$ & $\begin{array}{l}\text { Delivery volume from } \\
\text { the regional center to the } \\
\text { store during the reporting } \\
\text { period }\end{array}$ \\
\hline 7 & $\begin{array}{l}\text { Inbound to Store from } \\
\text { Supplier }\end{array}$ & $\begin{array}{c}\text { The volume of deliveries } \\
\text { to the store from direct } \\
\text { suppliers }\end{array}$ \\
\hline 8 & Total Inbound to Store & $\begin{array}{l}\text { The volume of deliveries } \\
\text { to the store }\end{array}$ \\
\hline 9 & Centralization $\% /$ & $\begin{array}{c}\text { Inbound to store from } \\
\text { DC/ Total Inbound to } \\
\text { Store }\end{array}$ \\
\hline 10 & $\begin{array}{l}\text { Pallets inbound to store } \\
\text { from DC }\end{array}$ & $\begin{array}{l}\text { Pallets inbound to store } \\
\text { from DC }\end{array}$ \\
\hline
\end{tabular}

\begin{tabular}{|c|c|c|}
\hline 11 & $\begin{array}{c}\text { Value per pallet inbound } \\
\text { to store from DC }\end{array}$ & $\begin{array}{c}\text { Inbound to store from } \\
\text { DC / Pallets inbound to } \\
\text { sore from DC }\end{array}$ \\
\hline 12 & Service level DC to Store & $\begin{array}{c}\text { Delivered to store / } \\
\text { Ordered amount }\end{array}$ \\
\hline 13 & KM per pallet HM only & KM per pallet HM only \\
\hline 14 & Own car fleet share & Own car fleet share \\
\hline 15 & Store availability & Promo/ regular \\
\hline
\end{tabular}

As test data source, an Excel file was used. It's containing basic indicators and their values.

To estimate the performance of supply chains, the main KPIs were identified, which are used on the OpenSearch tab. KPIs are grouped for easy using by users of the application (table 3).

TABLE III.

\begin{tabular}{|c|c|c|}
\hline Main KPIs & & \\
\hline $\begin{array}{l}\text { Packaging and other } \\
\text { material / pallets }\end{array}$ & Registered shrinkage & Stock-taking result \\
\hline $\begin{array}{l}\text { Canteen expenses / } \\
\text { FTE month } \\
\text { Rent income }\end{array}$ & $\begin{array}{l}\text { Stock provisions } \\
\text { Deductions from } \\
\text { salary }\end{array}$ & $\begin{array}{c}\text { Other margin } \\
\text { components } \\
\text { Advertising income }\end{array}$ \\
\hline $\begin{array}{l}\text { Personnel transport / } \\
\text { FTE month }\end{array}$ & Total stock losses & Total Goods margin \\
\hline $\begin{array}{l}\text { Canteen expenses + } \\
\text { Personnel transport / } \\
\text { FTE month }\end{array}$ & $\begin{array}{l}\text { Value difference } \\
\text { from average cost } \\
\text { price }\end{array}$ & $\begin{array}{l}\text { Logistic service } \\
\text { income }\end{array}$ \\
\hline $\begin{array}{c}\text { Total personnel costs } \\
\text { / FTE month }\end{array}$ & $\begin{array}{l}\text { Packaging and other } \\
\text { material }\end{array}$ & $\begin{array}{c}\text { Penalties to suppliers } \\
\text { etc }\end{array}$ \\
\hline Cash differences & Agency income & Sales of materials \\
\hline $\begin{array}{c}\text { Differences on } \\
\text { debitors and creditors }\end{array}$ & $\begin{array}{l}\text { Customer bonuses } \\
\text { accrued }\end{array}$ & $\begin{array}{l}\text { Other operating } \\
\text { income }\end{array}$ \\
\hline $\begin{array}{l}\text { Result from selling } \\
\text { fixed assets }\end{array}$ & $\begin{array}{l}\text { DC expenses } \\
\text { compensation }\end{array}$ & Total other income \\
\hline Total income & Wages & $\begin{array}{c}\text { Change in vacation } \\
\text { reservation }\end{array}$ \\
\hline $\begin{array}{c}\text { Overtime additonal } \\
\text { payments }\end{array}$ & $\begin{array}{c}\text { Total wages and } \\
\text { salaries }\end{array}$ & $\begin{array}{l}\text { Temporary } \\
\text { employees }\end{array}$ \\
\hline $\begin{array}{c}\text { Regular bonuses } \\
\text { (monthly, quarterly, } \\
\text { ann }\end{array}$ & $\begin{array}{l}\text { Special bonuses and } \\
\text { exit payments }\end{array}$ & $\begin{array}{l}\text { Medical insurance, } \\
\text { inspection }\end{array}$ \\
\hline $\begin{array}{c}\text { Training and } \\
\text { seminars }\end{array}$ & Recruitment costs & Personnel transport \\
\hline $\begin{array}{l}\text { Other contractual } \\
\text { compensations }\end{array}$ & $\begin{array}{l}\text { Entertainment } \\
\text { expenses }\end{array}$ & Total personnel costs \\
\hline Total housing costs & Ecology & $\begin{array}{l}\text { Property taxes and } \\
\text { land rent }\end{array}$ \\
\hline $\begin{array}{l}\text { Productivity (Pallets } \\
\text { inbound / FTE) }\end{array}$ & $\begin{array}{c}\text { Adjusted productivity } \\
\text { (Pallets inbound / } \\
\text { FTE) }\end{array}$ & $\begin{array}{c}\text { Productivity } \\
\text { (Adjusted / FTE) }\end{array}$ \\
\hline Rent of equipment & Supply chain costs & Materials usage \\
\hline $\begin{array}{l}\text { Quality assurance } \\
\text { costs }\end{array}$ & Total depreciation & $\begin{array}{c}\text { Total operational } \\
\text { costs }+ \text { depreciation }\end{array}$ \\
\hline
\end{tabular}

For each of the KPIs, the calculation is performed using QlikView functions.

Figure 1 shows the data model, which includes fact tables, reference books and system tables. System tables have no connections between themselves and with the main tables, since are inline loading inside the script. 


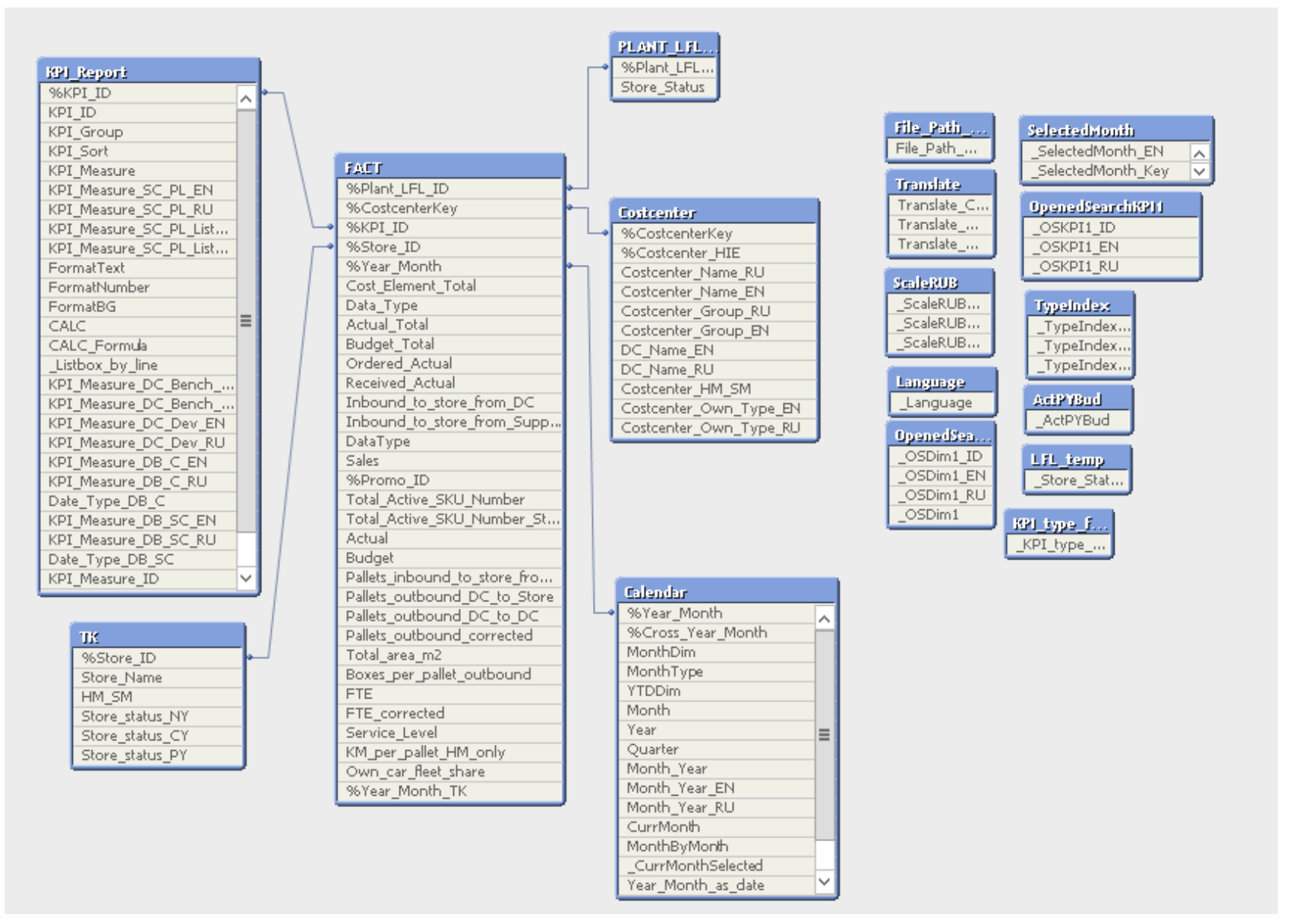

Fig. 1. Data model in QlikView.

Figure 2 shows the Dashboard, which includes the following objects in the main report area:

- output data switches in the block Centralization details: Pallets in DC, Centralized turnover, kRUB, Centralization, $\%$;

- output data switches in the Supply chain KPIs block: as\% of Centralized turnover, per pallet, in MRUB;

- 4 charts in the "Centralized turnover" block (vary depending on the switch);

- charts Total income and Total costs;

- 4 charts in the bottom report area.

Each of the charts shows the calculation results depending on the business requirements of the supply chain management service.

The report header (Figure 3) contains the main filters that allow users to generate a report on their own, depending on the date, period, language, type of TC, etc. Most of the objects are made in the list boxes form.
The right side of the report (Figure 4) contains the filter panel, which includes:

- "Current selections" field;

- filtration by store type(HM / SM);

- filtering by regional center. 


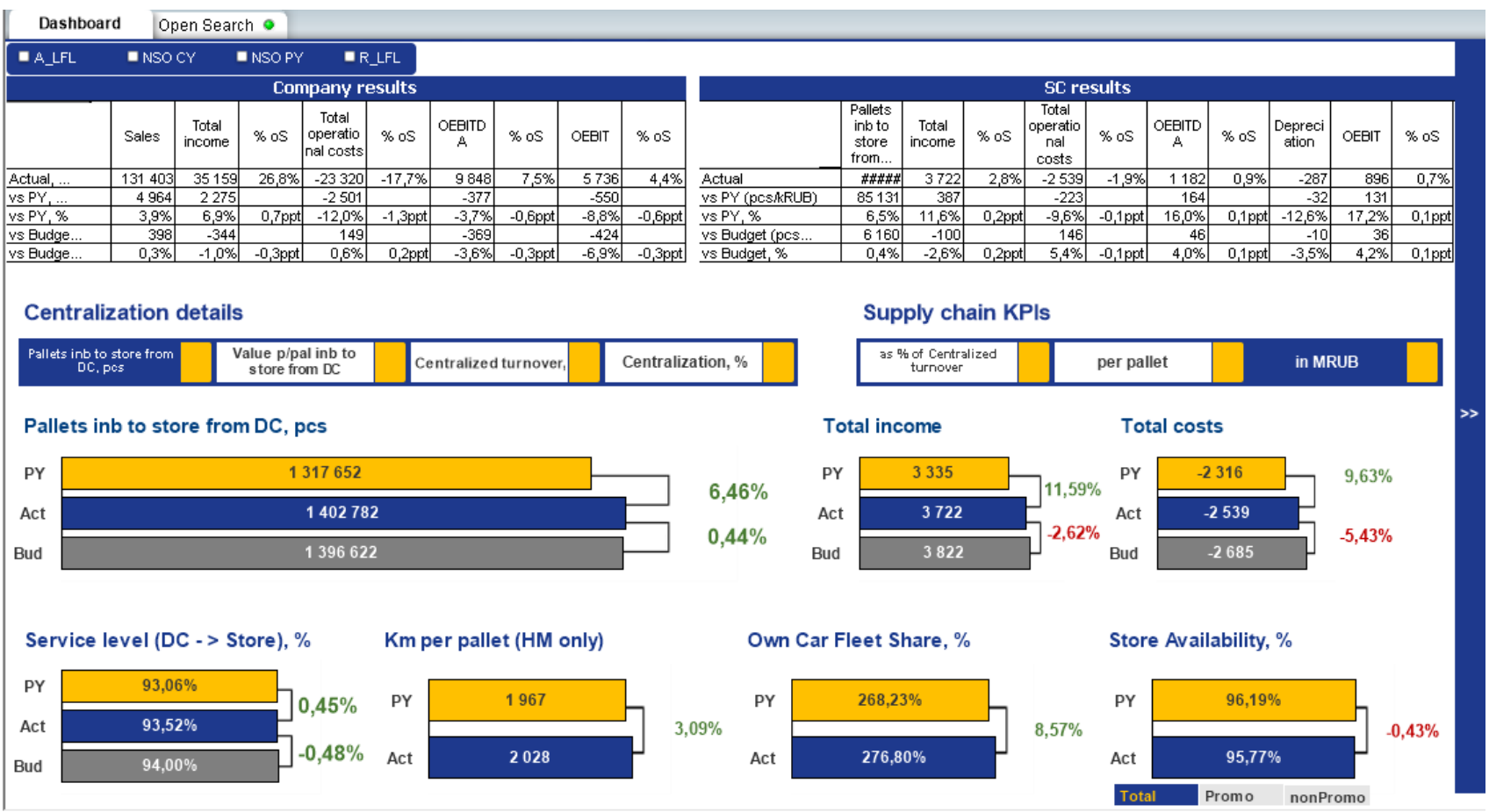

Fig. 2. Sheet «Dashboard»: main fields

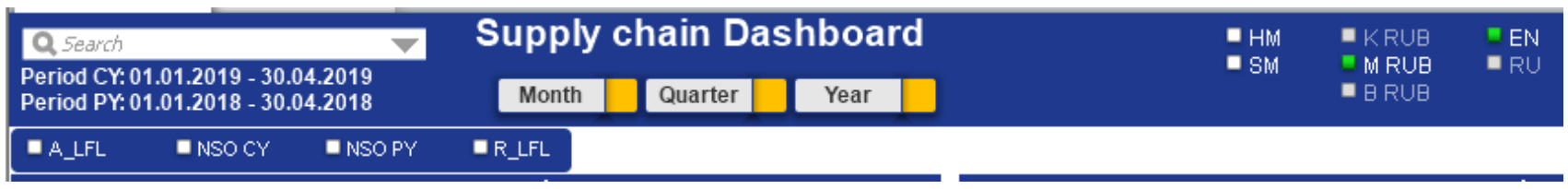

Fig. 3. Sheet «Dashboard»: top report area

\begin{tabular}{|l|}
\multicolumn{1}{c|}{ Filters } \\
\hline Current Selections \\
Month_Year 2- Apr19 \\
\\
\\
HM \\
\hline DC \\
7005 Shushary SM \\
7006 Chekhov-2-HM \\
8001 Shushary HM \\
8003 Obukhovo \\
8032 RND \\
8033 Novorossiysk \\
8052 Togliatti \\
8071 Novosibirsk \\
8072 Novosibirsk HM \\
8092 Ekaterinburg HM
\end{tabular}

- Design Table

- Switch: to date and by periods

- Switches output data by store type: TTL, HM, SM

To generate a report, it's necessary to select KPI and KPI Type.

Fig. 4. Sheet «Dashboard»: filter panel

Figure 5 shows the sheet OpenSearch. The main objects of this sheet are: 


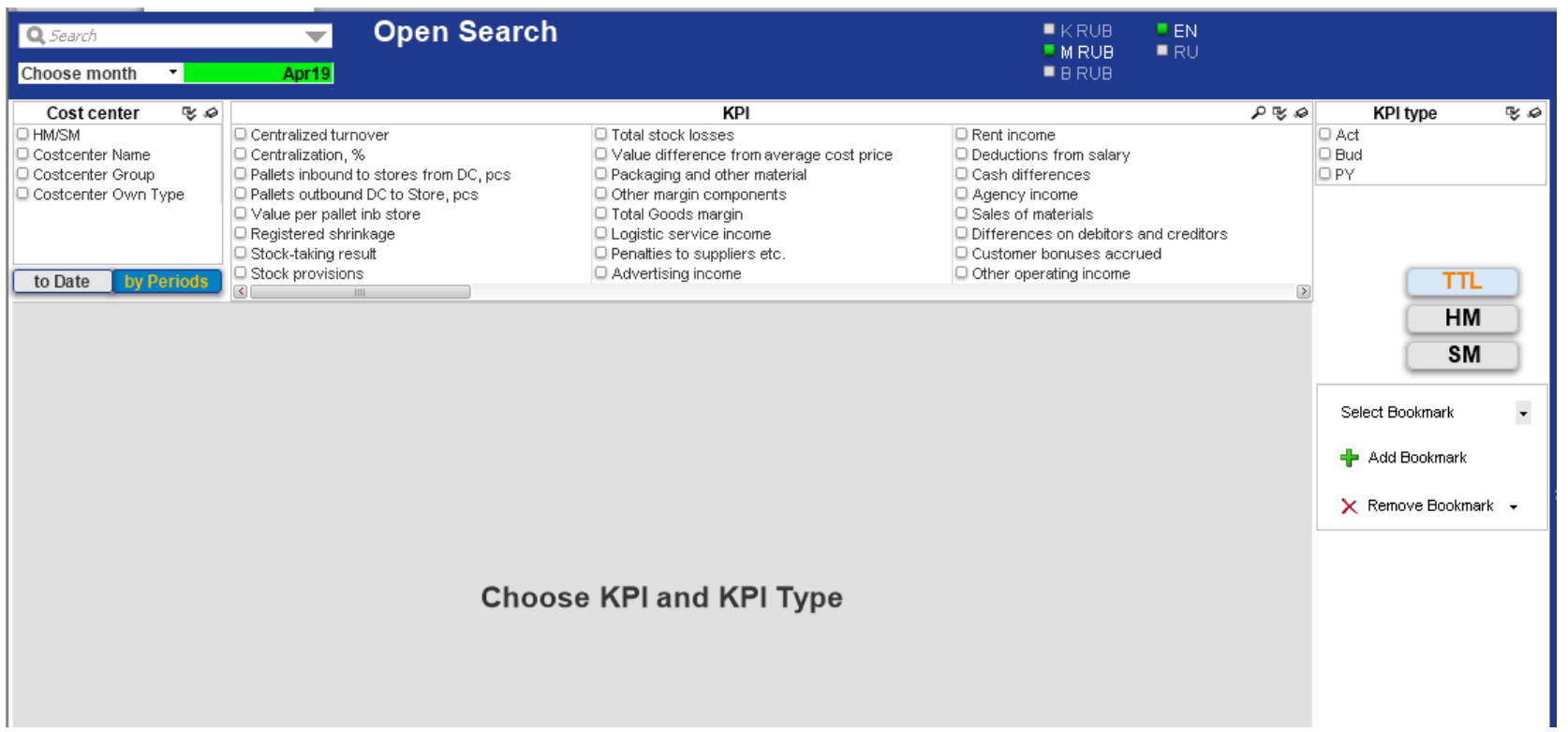

Fig. 5. Sheet «OpenSearch»: without current selections

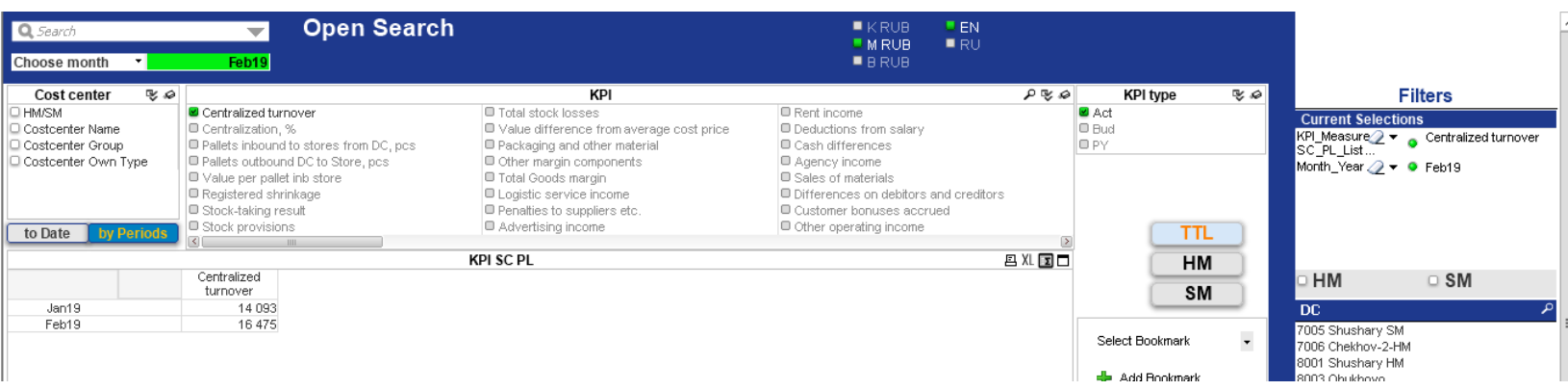

Fig. 6. Sheet «OpenSearch»: KPI selected, by Date.

\begin{tabular}{|c|c|c|c|}
\hline Choose month $\quad$ & Apr 19 & & \\
\hline Cost center $\quad \forall \theta$ & \multicolumn{3}{|c|}{ KPI } \\
\hline $\begin{array}{l}\square \text { HMISM } \\
\square \text { Costcenter Name } \\
\square \text { Costcenter Group } \\
\square \text { Costcenter Own Type }\end{array}$ & $\begin{array}{l}\text { Centralized turnover } \\
\square \text { Centralization, \% } \\
\square \text { Pallets inbound to stores from DC, pCs } \\
\square \text { Pallets outbound DC to Store, pCs } \\
\square \text { Value per pallet inb store } \\
\square \text { Registered shrinkage } \\
\square \text { Stock-taking result }\end{array}$ & $\begin{array}{l}\text { Total stock losses } \\
\square \text { Value difference from average cost price } \\
\square \text { Packaging and other material } \\
\square \text { Other margin components } \\
\square \text { Total Goods margin } \\
\square \text { Logistic service income } \\
\text { Q Penalties to suppliers etc. }\end{array}$ & $\begin{array}{l}\text { C } \\
\text { C } \\
\text { C } \\
\text { C } \\
\text { C } \\
\text { C } \\
\text { C }\end{array}$ \\
\hline to Date by Periods & $\begin{array}{l}\square \text { Stock provisions } \\
\text { (s) }\end{array}$ & $\square$ Advertising income & C \\
\hline
\end{tabular}

\begin{tabular}{|c|c|}
\hline & $\begin{array}{c}\text { Centralized } \\
\text { turnover }\end{array}$ \\
\hline Jan19 & 14093 \\
\hline Feb19 & 16475 \\
\hline Mar19 & 18504 \\
\hline Apr19 & 15466 \\
\hline
\end{tabular}

Fig. 7. Sheet «OpenSearch»: KPI selected, by Periods. 
The principle of the table is:

- selection of features displayed in the box list: Cost Center and KPI Type;

- KPI selection;

- report building according to the selected parameter.

During KPI selection, a report is generated in the form of a table in which the total value for the selected month and year is summed up (figure 6). To view the dynamics of changes in values, it is necessary to switch to the by Periods table mode, allowing you to view monthly values for the current year (YTD Calendar) (figure 7).

For the viewing convenience, the selected parameters on the OpenSearch sheet, the Current Selections block is provided on the filter panel, which allows to display current feature sets and KPIs.

\section{DISCUSSION}

The study identified further ways of developing the BI system application in the sector of supply chains in the retail segment companies, namely the automated QlikView system. It is planned to develop additional Dashboards with new KPIs and indicators that meet the business requirements of the retail company top management.

\section{CONSLUSION}

As part of the study implementation, the main BI systems were analyzed, allowing for an automatic analysis of company reports. We were considered foreign and Russian best practices. Based on the advantages of each system, QlikView was chosen to create a Dashboard. The main features were selected, the indicators and the main KPI of the Supply Chain sector in retail company were calculated. The result of the study is the creation of Dashboard and OpenSearch tabs, allowing to analyze the work of the Supply Chain Sector.

\section{ACKNOWLEDGMENT}

The reported study was funded by RSCF according to the research project № 19-18-00452

\section{REFERENCES}

[1] Ilin, I.V., Iliashenko, O.Y., Klimin, A.I., Makov, K.M. Big data processing in Russian transport industry (2018) Proceedings of the 31st International Business Information Management Association Conference, IBIMA 2018: Innovation Management and Education Excellence through Vision 2020, pp. 1967-1971.

[2] Ilin, I., Iliashenko, O., Iliashenko, V. Approach to the choice of Big Data processing methods in financial sector companies (2018) MATEC Web of Conferences, 193, статья № 05061

[3] Levina, A.I., Borremans, A.D., Burmistrov, A.N. Features of enterprise architecture designing of infrastructure-intensive companies (2018) Proceedings of the 31st International Business Information Management Association Conference, IBIMA 2018: Innovation Management and Education Excellence through Vision 2020, pp. 4643-4651.

[4] Krasyuk, I.A., Krymov, S.M., Medvedeva, Y.Y., Chernisheva, A.M., Lashko, S.I. Marketing management in retail chains (2017) 15 (12), pp. 83-91.

[5] Gutman, S.S., Zaychenko, I.M., Rytova, E.V. Development strategy of Far North transport infrastructure: Problems and prospects (2017) Proceedings of the 29th International Business Information Management Association Conference - Education Excellence and Innovation Management through Vision 2020: From Regional Development Sustainability to Global Economic Growth, pp. 14391449 .

[6] Kuleshova, E., Levina, A., Esedulaev, R. Reengineering of supply chain management integrated scheduling processes (2018) 193, 05064 .

[7] Ilin, I., Iliashenko, O., Iliashenko, V. Approach to the choice of Big Data processing methods in financial sector companies (2018) 193, 05061.

[8] Effective business analysis tools [Electronic source] URL:https://analytikaplus.ru/

[9] Tableau Clients [Electronic source] URL:https://analytikaplus.ru/nov ye-klienty-tableau/

[10] Overview of dashboard systems [Electronic source] https://www.uplab.ru/blog/review-systems-for-creating-dashboards/

[11] Data visualization tools [Electronic source] https://www.qlik.com/ru-

[12] Three fundamental differences between QlikView and traditional BI systems [Electronic source]https://biconsult.ru/products/trifundamentalnyh-otlichiya-qlikview-ot-tradicionnyh-bi-sistem

[13] What is it - Power BI? [Electronic source] https://powerbi.microsoft.com/ru-ru/

[14] Demand forecasting [Electronic source] https://www.managementstu dyhq.com/demand-forecasting-in-human-resource.html

[15] Nenkov Nayden, Varbanov Stefan. Application of intelligent business system within the administrative information system for complex services // International Journal of Innovative Technologies in Economy. ISSN 2412-8368

[16] Oleg Troyansky, Tammy Gibson, Charlie Leichtweis. QlikView Your Business. An Expert Guide to Business Discovery with QlikView ${ }^{\circledR}$ and Qlik Sense (2015). - WILEY. 759 pp. 